\title{
Spirituality and Health in Brazil: A Survey Snapshot of Research Groups
}

\author{
Mary Rute Gomes Esperandio
}

Postgraduate Program in Bioethics/Postgraduate Program in Theology, Pontifical Catholic University of Paraná—PUCPR, Rua Imaculada Conceição, Curitiba, PR 1155, Brazil; mary.esperandio@pucpr.br

\begin{abstract}
Articles on "Spirituality and Health" have multiplied considerably in Brazil in the last decade. More recently, however, research groups created specifically to investigate this topic have emerged. This study aims to provide an overview of the field by means of a survey in the Directory of Research Groups in Brazil. Thirty-three groups were initially identified, of which 16 were selected for analysis and placed into two categories: "established" groups and lines of research, and "in-process" groups and lines of research. The survey made it possible to identify postgraduate programs that develop studies on this theme, the main researchers, and the potentials and challenges of this research field in Brazil. The results also indicate that "Spirituality and Health" is a fundamentally interdisciplinary field of research that is expanding and has gained greater legitimacy in the scientific community in the last four years. The main challenges to and potentials for advancement of knowledge are the need for theoretical and methodological development to support research, educational improvement in spiritual care, development of a critical and conscious reflection on the political implications of the field (especially due to the religious diversity in the Brazilian cultural context), and the role of spirituality/religiosity in public health promotion policies.
\end{abstract}

Keywords: research group; research lines; spirituality and health; Brazil; interdisciplinarity

Citation: Esperandio, Mary Rute Gomes. 2021. Spirituality and Health in Brazil: A Survey Snapshot of Research Groups. Religions 12: 27. https://doi.org/10.3390/rel12010027

Received: 30 October 2020 Accepted: 29 December 2020 Published: 31 December 2020

Publisher's Note: MDPI stays neutral with regard to jurisdictional clai$\mathrm{ms}$ in published maps and institutional affiliations.

Copyright: $\odot 2020$ by the author. Licensee MDPI, Basel, Switzerland. This article is an open access article distributed under the terms and conditions of the Creative Commons Attribution (CC BY) license (https:// creativecommons.org/licenses/by/ $4.0 /)$.

\section{Introduction}

"Religious influence is harmful to health and puts lives at risk" (Oliveira 2020). This statement is taken from an interview with Brazilian gynecologist Cristião Rosas by journalist Joana Oliveira for the newspaper El País on 30 August 2020. The interview was motivated by the reaction of Brazilian society to the issue of the right to legal abortion. A case, widely publicized in the media, told the story of a pregnant 10-year-old girl who had been sexually abused by her uncle since the age of six and was thus guaranteed the legal right to abortion. Nevertheless, the case caused a series of demonstrations by religious radicals.

The gynecologist's statement represents some Brazilian healthcare professionals' understanding of the relationship between spirituality, religion, and health. Such an understanding likely results from a lack of training on the adequate integration of spirituality in healthcare, as some Brazilian researchers have pointed out (Costa et al. 2010; Lucchetti et al. 2012, 2013; Cavalheiro and Falcke 2014; Esperandio and Machado 2018; Menegatti-Chequini et al. 2019).

Although the last Brazilian religious census (Instituto Brasileiro de Geografia e Estatística IBGE) pointed to significant growth in the number of atheists and agnostics ( $8 \%$ of a population of 191 million), $92 \%$ of the Brazilian population still declare themselves as belonging to a religion or as having "multiple religious belongings". Studies by Huber and Huber (2012) and Esperandio et al. (2019) also show that Brazilians are a "highly religious" population.

Despite this high level of religiosity, the discussion of how spiritual/religious beliefs and behavior can impact health outcomes is not yet fully included in the curricula of psychology courses (Costa et al. 2010; Esperandio and Marques 2015; Pereira and Holanda 2019) or in medical courses (Lucchetti et al. 2012, 2013; Menegatti-Chequini et al. 2019) or 
in nursing courses (Oliveira 2017; Espinha et al. 2013). However, this scenario has been changing significantly, perhaps as a result of international research and the academic interest of Brazilian researchers, who seem to feel more freedom to develop research on the subject with the scientific rigor required in the academy. This increased interest can also be substantiated by the number of new research groups working on this topic.

In Brazil, the Ministry of Education organizes, monitors, and promotes the development of scientific knowledge via two government agencies- the Coordination for the Improvement of Higher Education Personnel (CAPES) and the National Council for Scientific and Technological Development (CNPq). CAPES' main objective "is to coordinate efforts to improve the quality of Brazil's faculty and staff in Brazil in higher education through grant programs" (Brazil, Ministério da Educação 2020b). CNPq acts as the agency responsible for "conceptualizing and conducting public policies on science, technology, and innovation. Its performance is essential for the national development and international recognition of Brazilian research institutions and researchers" (Ministério da Educação 2020a). By means of the Directory of Research Groups, CNPq monitors the development of science in higher education institutions and produces statistical data on the various areas of knowledge. Researchers working in stricto sensu graduate programs are encouraged to form research groups around the main topic of their research. Graduate students and undergraduate students (who are involved in scientific research projects) have to be registered in the research groups formally established in their faculties, and these groups are then registered in the Directory of Research Groups on the CNPq platform. So, when the intention is to map (a) the development of a specific research topic, (b) areas of knowledge where research on the topic is developed, (c) leading researchers, (d) geographical location, and (e) postgraduate programs where the topic has been developed, the search for Groups of Research registered in the Directory of Research Groups in Brazil is a useful strategy.

It is worth highlighting that if one wishes to verify gaps and needs for additional research or to identify conflicts in previous studies or unanswered questions about a particular topic, a literature review is a good strategy. However, a literature review alone cannot provide information about the researchers and the context from which the studies originate. A survey of research groups is useful to identify groups of researchers who are developing research around a common specific theme. It is also possible to identify the evolution of the interest in the topic in the academic scenario.

A search was conducted in the Directory of Research on the platform of the National Council for Scientific and Technological Development (CNPq) with the aim of answering the following question: which groups are working in the field of Spirituality and Health $(\mathrm{S} \& \mathrm{H})$ in Brazil and what are the main themes of their research? Thus, this study provides a snapshot of the current field of S\&H research in Brazil.

\section{Methodological Procedures}

According to the current census of research groups (based on the last quadrennium of national assessment from 2013 to 2016), there are 8091 research groups in the humanities and 5877 in health sciences in Brazil. The Directory of Research Groups User Manual (Conselho Nacional de Desenvolvimento Científico e Tecnológico CNPq) from the CNPq defines a research group

as a group of individuals that are hierarchically organized around one or, eventually, two leaders; with the organizing foundation of this hierarchy being: experience, prominence and leadership in the scientific or technological field; professional and permanent involvement in the research activity; work organized around common lines of research that are subordinate to the group (and not the other way around); and, to some degree, shared facilities and equipment. The concept of group may be that composed of only one researcher and his or her students.

Group leaders must hold a doctorate degree, and research groups are regulated by CNPq. The glossary, also available on the DRG website, defines technical terms such as: 
1. Institutionally certified group: certified and updated group that participates in the directory census.

2. Not updated group: certified group with no updates for more than 12 (twelve) months. The leader has 12 (twelve) months to update a group in this situation. After this period, the group's status will automatically change to "excluded" and can no longer be recovered in the database by the leader or the person representing the institution in which the research group is housed. The Research Officer can certify or withdraw certification from a not updated group, changing its status to "Certification Denied". A not updated group does not participate in the directory's censuses but is available for examination in the public search of the DRG portal (in Search Groups, Current Base) for a maximum period of 12 months. If there are no updates during this period, that group is excluded from the database.

3. Predominant area of the group: area of knowledge that most closely matches the group's research activities, among those existing in the classification of areas of knowledge used by CNPq. Even multidisciplinary and interdisciplinary groups must be related to an area that coordinates their activities. The research lines of a research group can be associated with up to three areas of knowledge and subareas or specialties.

4. Research Lines: represent unified themes of scientific studies based on an investigative tradition, developing projects whose results are related to each other. Because research lines are subordinate to groups, groups can have one or more lines, and they do not necessarily need to be associated with all members of the group.

To verify which groups are leading the field on S\&H (including their quantity of output, predominant disciplines from where they originate and in which universities they are anchored, and their main themes of research), a search in the Directory of Research Groups was carried out on two occasions in 2020 (September 23, and October 3) using the term "spirituality and health" with search application in the following fields: group's name, research line, and keyword of research line. The search contained no limitations on the duration of a group's registration in the directory.

The groups selected for analysis had to meet the following criteria: (1) To have a specific focus on S\&H or at least one research line for $\mathrm{S} \& \mathrm{H}$ in conjunction with their main research focus; (2) To include both researchers and students; (3) To present scientific publications resulting from their research on the topic; (4) To be "certified by the institution". "Not updated" research groups (still within the deadline for regularization) and research groups "in completion" (as long as they had students linked to their lines of research and scientific publications by the researchers) were also selected. Groups that did not meet these established inclusion criteria were excluded.

The Directory of Research Groups does not list the researchers' scientific publications, but it does provide a link to the Lattes platform (Supplementary Materials). The Lattes platform is "the major scientific information system maintained by the National Council for Scientific and Technological Development (CNPq) [that] allows to manage the curricular information of researchers and institutions working in Brazil based on the so-called Lattes Curriculum" (Mena-Chalco and Junior 2009, p. 31). Thus, a search of all Lattes Curricula of research group leaders and researchers listed in the S\&H line of research was carried out on the Lattes platform in order to extract their specific research foci and scientific publications related to the field. This analysis permitted us to categorize the groups and lines of research into two categories: "established" groups and lines of research, and "in-process" groups and lines of research.

"Established" groups and lines of research were those groups (a) with a primary focus on S\&H; (b) researchers who regularly publish results of their studies, and (c) whose publications on the topic were prior to the creation of the research group. "In-process" were: (a) recently created groups (without publications) or groups that added S\&H as a research line to an existing group, (b) groups whose scientific publications were not on $\mathrm{S \& H}$, or not regular (e.g., despite the registration of several researchers in a research group/line of research, only a single researcher has a single publication). The research topics, as well as 
the details of the scientific publications of all researchers involved in the groups and lines of research, can be verified in their Lattes Curricula, which are available on the Internet. The addresses to access such curricula are provided in the Supplementary Materials.

\section{Results}

Research groups in the humanities represent $21.5 \%$ of the total research groups registered in the Directory of Research Groups (DRG), while health sciences represent $15.6 \%$ of the total. Humanities and health sciences are the two major research categories to which $\mathrm{S} \& \mathrm{H}$ research groups are linked.

The two searches discovered a total of 33 unique groups, 16 of which met the selection criteria for analysis. Those 17 groups not included in the analysis were discarded for the following reasons: (1) the group had no focus on S\&H or any line of research on the topic; (2) the words "spirituality" or "health" were mentioned but without any relation to S\&H; (3) no students were registered in the group; (4) none of the researchers listed in the line of research had any publications on S\&H. The last criterion for exclusion was based on the understanding that at least one researcher involved in a research group (or in a line of research) should have published accordingly.

The leading areas of knowledge for the groups with a main focus on S\&H or with a line of research on the topic are shown in Table 1.

Table 1. Distribution of research groups according to the predominant area of knowledge in the group's activities.

\begin{tabular}{lcccc}
\hline & Area of Knowledge & $\begin{array}{c}\text { Number of Groups } \\
\text { in the DRG }\end{array}$ & $\begin{array}{c}\text { \% in the } \\
\text { DRG }\end{array}$ & $\begin{array}{c}\text { RG with a Specific Focus or Research } \\
\text { Line on Spirituality \& Health }\end{array}$ \\
\hline 1 & Anthropology & 393 & 1 & 1 \\
\hline 2 & Bioethics & 5 & 0 & 1 \\
\hline 3 & Education & 3595 & 9.6 & 1 \\
\hline 4 & Nursing & 683 & 1.8 & 5 \\
\hline 5 & Medicine & 1619 & 4.3 & 2 \\
\hline 6 & Psychology & 884 & 2.4 & 3 \\
\hline 7 & Public Health & 1079 & 2.9 & 1 \\
\hline 8 & Theology & 104 & 0.3 & 2 \\
\hline
\end{tabular}

\subsection{Geographical Location of Research Groups in Brazil}

The 16 research groups which met the criteria were located in just eight states in Brazil (Figure 1); the red spots mark their distribution on the map. Ten of the 16 groups are situated in Southeast Brazil (the yellow part of the map).

\subsection{Categorization and Evolution of Groups and Lines of Research}

The analysis of the 16 groups shows that nine of them fall into the category of "established" groups and lines of research (Table 2), and seven of them can be categorized as "in-process" groups and lines of research (Table 3). Tables 2 and 3 also provide information about when the groups were created and, if relevant, when a S\&H line of research was added to an existing group. If a research line on $\mathrm{S} \& \mathrm{H}$ was added later, it follows the slash in the second column, e.g., 2013/2016 (Tables 2 and 3).

The first research group with a primary focus on S\&H appeared in the directory in 2013 (Table 2), while the first S\&H line of research was added to a research group (on Palliative Care and Health Quality of Life) in 2011. The evolution of the groups and lines of research is presented in Figure 2. "In-process" groups and lines began their activities in 2016. 
Table 2. Established research groups with main focus on Spirituality and Health (RG) or research lines (RL) on Spirituality and Health.

\begin{tabular}{|c|c|c|c|c|c|c|c|c|}
\hline & $\begin{array}{l}\text { Research Group or } \\
\text { Research Line (RL) }\end{array}$ & $\begin{array}{l}\text { Year of } \\
\text { Creation }\end{array}$ & Localization & State & $\begin{array}{l}\text { Area of } \\
\text { Knowledge }\end{array}$ & Leaders & Research Line & Scientific Publications-Topics \\
\hline $\begin{array}{l}1 \\
\text { RL }\end{array}$ & $\begin{array}{l}\text { Palliative Care and Health- } \\
\text { Related Quality of Life } \\
\text { (9 RL) }\end{array}$ & 2011 & $\begin{array}{l}\text { Pio XII Foundation } \\
\text { Barretos }\end{array}$ & SP & Medicine & Paiva, BSR; Paiva, CE & $\begin{array}{l}\text { Spirituality and Religiosity } \\
\text { and their implications in } \\
\text { the area of Health }\end{array}$ & $\begin{array}{l}\text { Prayer; cancer patients and quality of life; health } \\
\text { professionals and integration of } S / R \text { in care }\end{array}$ \\
\hline $\begin{array}{l}2 \\
R G\end{array}$ & $\begin{array}{l}\text { Religiosity and Spirituality } \\
\text { in Whole Health (RSWH) }\end{array}$ & 2013 & $\begin{array}{l}\text { UNASP_Adventist } \\
\text { University of São Paulo } \\
\text { —SP }\end{array}$ & SP & Nursing & Meira, MDD; Abdala, GA & $\begin{array}{l}\text { Health promotion in the } \\
\text { family with attention to } \\
\text { mental and spiritual health } \\
\text { and health education }\end{array}$ & $\begin{array}{l}\text { Lifestyle and religiosity; Quality of life; } \\
\text { Adventism, religiosity and health of } \\
\text { various populations }\end{array}$ \\
\hline $\begin{array}{l}4 \\
\mathrm{RL}\end{array}$ & $\begin{array}{l}\text { Qualitative Translational } \\
\text { Research Center on } \\
\text { Emotions and Spirituality } \\
\text { in Health } \\
\text { (5 Research Lines) }\end{array}$ & $2013 / 2016$ & $\begin{array}{l}\text { UFF-Fluminense Federal } \\
\text { University—Niterói }\end{array}$ & RJ & Nursing & Pereira, ER; Silva, RMCRA & $\begin{array}{l}\text { Spirituality and } \\
\text { spiritual care }\end{array}$ & $\begin{array}{l}\text { Spiritual care in nursing; elderly in long-term } \\
\text { care facilities; meaning of life and nursing } \\
\text { professional; cancer patients; people living } \\
\text { with HIV }\end{array}$ \\
\hline $\begin{array}{l}5 \\
\text { RG }\end{array}$ & $\begin{array}{l}\text { Spirituality / Religiosity in } \\
\text { the context of Nursing and } \\
\text { Health Care: Discursive } \\
\text { Production and Social } \\
\text { Representations }\end{array}$ & 2016 & $\begin{array}{l}\text { UERJ-Rio de Janeiro State } \\
\text { University }\end{array}$ & RJ & Nursing & Gomes, AMT; Marques, SC & $\begin{array}{l}\text { Spirituality in the context } \\
\text { of nursing and health care; } \\
\text { Religiosity in the context of } \\
\text { nursing and health care }\end{array}$ & $\begin{array}{l}\text { Social representations of } \mathrm{S} / \mathrm{R} \text { in people living } \\
\text { with HIV; drugs and treatment; } \\
\text { spiritual/religious coping }\end{array}$ \\
\hline $\begin{array}{l}6 \\
\text { RG }\end{array}$ & $\begin{array}{l}\text { Research Center in } \\
\text { Bioethics and } \\
\text { Spirituality-NUBE } \\
\text { (2 Research Lines) }\end{array}$ & $2013 / 2018$ & $\begin{array}{l}\text { UESB-State University of } \\
\text { Southwest Bahia-Jequié }\end{array}$ & BA & Bioethics & Yarid, SD & Spirituality and Health & $\begin{array}{l}\text { Spiritual/Religious coping and maternal grief; } \\
\text { ICU Health professionals and job well-being; } \\
\text { S/R in the Brazilian Public Health System (SUS) }\end{array}$ \\
\hline $\begin{array}{l}7 \\
\mathrm{RL}\end{array}$ & $\begin{array}{l}\text { Center for Studies and } \\
\text { Research on the } \\
\text { Elderly-NESPI } \\
\text { (7 Research Lines) }\end{array}$ & $1973 / 2017$ & $\begin{array}{l}\text { UFBA-Federal University } \\
\text { of Bahia-Salvador }\end{array}$ & BA & Nursing & $\begin{array}{l}\text { Menezes, TMO; } \\
\text { Pedreira, LC }\end{array}$ & Spirituality and Health & $\begin{array}{l}1 \text { researcher-review and empirical studies on } \\
\mathrm{S} / \mathrm{R} \text { and Health of elderly patients, family } \\
\text { members and professionals }\end{array}$ \\
\hline $\begin{array}{l}8 \\
\mathrm{RG}\end{array}$ & $\begin{array}{l}\text { Spirituality and Health } \\
\text { Research Group }\end{array}$ & 2019 & $\begin{array}{l}\text { PUCPR } \\
\text { Pontifical Catholic } \\
\text { University of } \\
\text { Paraná-Curitiba }\end{array}$ & PR & Theology & $\begin{array}{l}\text { Esperandio, MRG } \\
\text { (PUCPR); Freitas, } \\
\text { MH (UCB) } \\
\text { (Research prior to } \\
\text { RG registration) }\end{array}$ & $\begin{array}{l}\text { Bioethics and Palliative } \\
\text { Care; Theology and Society, } \\
\text { Mental health and } \\
\text { therapeutic actions }\end{array}$ & $\begin{array}{l}\text { Palliative care; spiritual care; spiritual/religious } \\
\text { coping; scale validation; prayer; health } \\
\text { professionals and integration of } \mathrm{S} / \mathrm{R} \text { in care; } \\
\text { chaplaincy and mental health; } \\
\text { health professionals }\end{array}$ \\
\hline
\end{tabular}


Table 2. Cont

\begin{tabular}{|c|c|c|c|c|c|c|c|c|}
\hline & $\begin{array}{l}\text { Research Group or } \\
\text { Research Line (RL) }\end{array}$ & $\begin{array}{l}\text { Year of } \\
\text { Creation }\end{array}$ & Localization & State & $\begin{array}{l}\text { Area of } \\
\text { Knowledge }\end{array}$ & Leaders & Research Line & Scientific Publications-Topics \\
\hline $\begin{array}{l}9 \\
\text { RG }\end{array}$ & $\begin{array}{l}\text { CURAS-Spirituality } \\
\text { and Health } \\
\text { Research Group }\end{array}$ & 2020 & $\begin{array}{l}\text { UFPB-Federal University } \\
\text { of Paraíba-João Pessoa }\end{array}$ & PB & Theology & $\begin{array}{l}\text { Cavalcanti, APR (UFPB); } \\
\text { Valente, TCO (UFRJ) } \\
\text { (Research prior to } \\
\text { RG registration) }\end{array}$ & Spirituality and Health & Patients living with HIV; scale validation \\
\hline
\end{tabular}

Table 3. "In-process" groups and lines of research.

\begin{tabular}{|c|c|c|c|c|c|c|c|}
\hline & $\begin{array}{l}\text { Research Group or } \\
\text { Research Line (RL) }\end{array}$ & $\begin{array}{l}\text { Year of } \\
\text { Creation }\end{array}$ & Localization & $\begin{array}{l}\text { Area of } \\
\text { Knowledge }\end{array}$ & $\begin{array}{l}\text { Number of } \\
\text { Researchers }\end{array}$ & Researchers with Scientific Publication & Research Line \\
\hline 1 & $\begin{array}{l}\text { Inter Psi-Laboratory of } \\
\text { Psychosocial Studies: belief, } \\
\text { subjectivity, culture \& health } \\
\text { (6 Research Lines) }\end{array}$ & $2010 / 2016$ & $\begin{array}{l}\text { USP-University of } \\
\text { São Paulo-São Paulo }\end{array}$ & Psychology & 4 & $\begin{array}{l}\text { Breno, } \mathrm{M} \\
\text { (1 production: health concepts of holistic therapists) }\end{array}$ & $\begin{array}{l}\text { Belief, religiosity, spiritualities } \\
\text { and health }\end{array}$ \\
\hline 2 & $\begin{array}{l}\text { Education and Health Studies } \\
\text { (4 Research Lines) }\end{array}$ & $2014 / 2016$ & $\begin{array}{l}\text { UFCSPA-Federal } \\
\text { University of Health } \\
\text { Sciences of Porto Alegre }\end{array}$ & $\begin{array}{l}\text { Health } \\
\text { Education }\end{array}$ & 13 & $\begin{array}{l}\text { Costa, MR } \\
\text { ( } 2 \text { productions: teaching S/R for medical students; S/R } \\
\text { in the Brazilian Public Health System-SUS) }\end{array}$ & $\begin{array}{l}\text { Spirituality in Education } \\
\text { and Health }\end{array}$ \\
\hline 3 & $\begin{array}{l}\text { ORÍ - Psychology, Health and } \\
\text { Society Research Laboratory } \\
\text { (3 Research Lines) }\end{array}$ & 2018 & $\begin{array}{l}\text { USP-University of } \\
\text { São Paulo—Ribeirão Preto }\end{array}$ & Psychology & 2 & $\begin{array}{l}\text { Scorsolini-Comin, F } \\
\text { (experience reports, case study, } 2 \text { empirical articles: } \\
\text { psychotherapists; complaints of illness by } \\
\text { Umbanda supporters } \\
\text { (Also researcher at RG 6) }\end{array}$ & $\begin{array}{l}\text { Religiosity/spirituality in } \\
\text { health care }\end{array}$ \\
\hline 4 & $\begin{array}{l}\text { CuraRe: Collective of Studies on } \\
\text { Religion and Healing } \\
\text { (3 Research Lines) }\end{array}$ & 2018 & $\begin{array}{l}\text { UFAL-Federal } \\
\text { University of Alagoas }\end{array}$ & Anthropology & 6 & $\begin{array}{l}\text { Rose, IS } \\
\text { ( } 2 \text { productions: empirical research on Santo Daime and } \\
\text { the Spiritism Center) }\end{array}$ & Religion, spirituality and health \\
\hline 5 & $\begin{array}{l}\text { Cardiovascular Health } \\
\text { Research Group } \\
\text { (7 Research Lines) }\end{array}$ & $2016 / 2020$ & $\begin{array}{l}\text { UFU_Federal University } \\
\text { of Uberlândia }\end{array}$ & Nursing & 6 & $\begin{array}{l}\text { Scalia, LAM } \\
\text { (2 productions: experience report; empirical research } \\
\text { on spiritism passes and health effects) }\end{array}$ & $\begin{array}{l}\text { Spirituality / religiosity and } \\
\text { cardiovascular health }\end{array}$ \\
\hline 7 & $\begin{array}{l}\text { Spirituality and Health } \\
\text { Research Group }\end{array}$ & 2020 & $\begin{array}{l}\text { UFRJ-Federal University } \\
\text { of Rio de Janeiro }\end{array}$ & $\begin{array}{l}\text { Collective } \\
\text { Health }\end{array}$ & 6 & $\begin{array}{l}\text { Moreira-Almeida, A } \\
\text { (External researcher-UFJF-vast production linked to } \\
\text { NUPES-see Section 4.1) }\end{array}$ & $\begin{array}{l}\text { Environmental health and mental } \\
\text { well-being; Well- being and mental } \\
\text { disorders; Well-being and quality } \\
\text { of life; Science and spirituality: } \\
\text { personality and its contributions }\end{array}$ \\
\hline
\end{tabular}




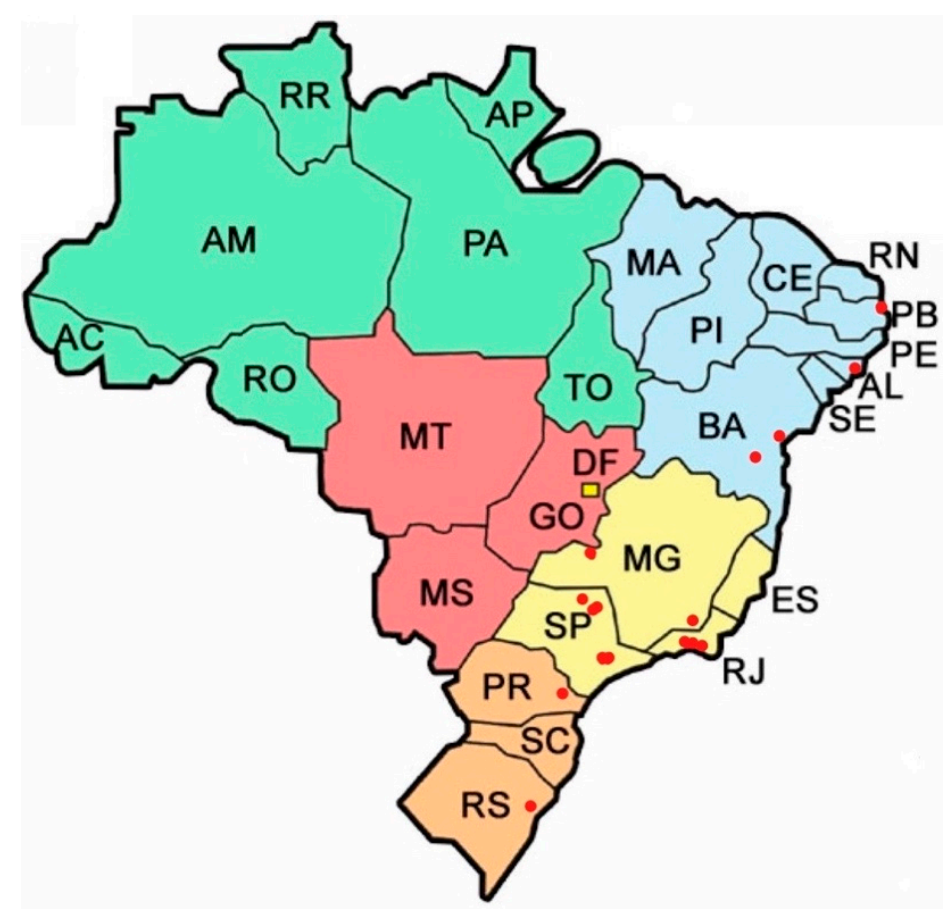

Figure 1. Federative units with higher education institutions that house research groups in Spirituality and Health.

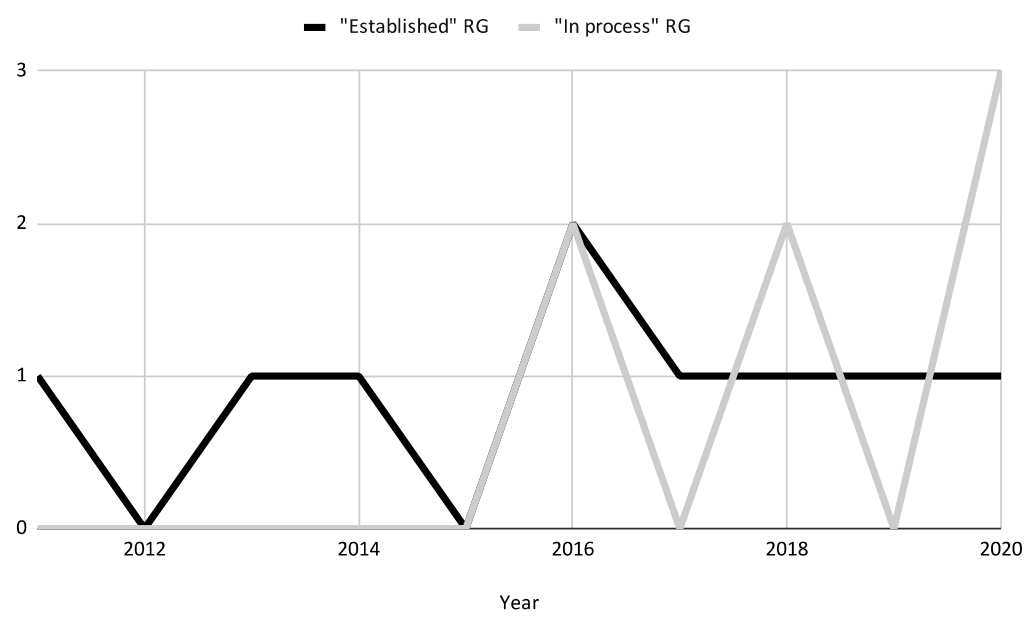

Figure 2. Evolution of the groups and lines of research.

According to the survey, there are five established research groups with a primary focus on S\&H in the following disciplines: nursing, medicine, religious studies, and theology. They are housed in the following programs: (1) Postgraduate Program in Health, School of Medicine at the Federal University of Juiz de Fora-Minas Gerais; (2) Postgraduate Program in Theology at the Pontifical Catholic University of Paraná, in Curitiba-Paraná; (3) Postgraduate Program in Health Promotion at the Adventist University of São PauloSP; (4) Postgraduate Program in Nursing and Health Sciences, at the Fluminense Federal University, Rio de Janeiro; (5) Postgraduate Program in Sciences of Religions at the Federal University of Paraíba, in João Pessoa.

\subsection{Main Topics Investigated in the Groups and Lines of Research}

Based on the publications in the Lattes Curriculum, researchers in the selected groups investigated the following topics: 
(a) Quality of life in several contexts and populations: in situations of illness (Carvalho et al. 2019), older people (Santos and Abdala 2014; Veras et al. 2019; Reis et al. 2016); people with HIV / AIDS (Gomes et al. 2020), and mental health (Lucchetti et al. 2018; Mainieri et al. 2017; Nwora and Freitas 2020).

(b) The lack of S\&H training for students and health professionals (Cavalheiro and Falcke 2014; Costa et al. 2019; Lucchetti and Granero 2010; Aguiar et al. 2017).

(c) Integration of spirituality into healthcare (Esperandio 2014; Moreira-Almeida et al. 2006; Sens et al. 2019; Cunha and Comin 2019; Oliveira et al. 2018).

(d) Relationship between spirituality/religiosity and health in the general population (Lucchetti et al. 2013; Cavalcanti et al. 2012; Moreira-Almeida et al. 2010).

(e) Prayer and health (Esperandio and Ladd 2015); prayer and cancer patients (Paiva et al. 2015; Paiva et al. 2014).

(f) Spiritual/religious coping (Matos et al. 2017; Silva et al. 2019; Vitorino et al. 2018).

(g) Meaning-making (Rocha et al. 2018a; Silva et al. 2020).

(h) Creation and validation of instruments for assessing spirituality (Abdala et al. 2020; Esperandio et al. 2018; Oliveira da Silva et al. 2020a, 2020b; Curcio et al. 2015; Silva et al. 2018).

\section{Discussion}

This mapping made it possible to identify both the postgraduate programs where this field of research is concentrated and the research groups whose leaders have contributed regularly to scientific publications. Research groups are housed in several areas of the humanities and health sciences, indicating that Spirituality and Health is an intrinsically interdisciplinary field. Within Brazil, this study shows that one-third of the research groups, $31.25 \%$, are situated in São Paulo. This study also indicates that concentrated research on this topic is relatively recent; most groups and lines of inquiry have begun within the last decade.

It is noteworthy to highlight the number of current research lines added to research groups that previously did not address S\&H (especially in the last four years). This indicates an increasing interest in the field and calls for more investigation on why this field of knowledge is now gaining attention (or legitimacy) within the academic community. This may be associated with a new understanding of the differentiation between spirituality and religiosity, as pointed out by Esperandio and Leget (2020, p. 38) in their literature review; this hypothesis should be investigated further.

The analysis of the Lattes Curriculum (for all researchers) indicates that, especially among the newest groups or research lines, there are few scientific publications. This recent "enthusiasm" for S\&H could be understood as merely a "fad", but it could also indicate that scholars are beginning to pursue interests that they have hitherto left unexplored for any number of reasons. Therefore, it is possible to foresee an "explosion" of articles and journals on $\mathrm{S} \& \mathrm{H}$ by Brazilian scholars in the future, judging by the large number of researchers and students currently engaged in these research lines. The growing interest in this field was most evident recently, in 2020, as one new group with a primary focus on S\&H formed, and unique S\&H research lines were added to three existing groups. When one considers the main topics currently under investigation, one can also see that some themes have been insufficiently researched and should receive more attention in the future: models of spiritual care, the role of chaplains/spiritual caregivers, and training for healthcare professionals on how to adequately integrate spirituality into healthcare, among other themes.

While the first group was listed in the directory in 2013, studies on S\&H have actually been carried out by a group of researchers from the Federal University of Juiz de Fora at the Center for Research on Spirituality and Health-NUPES- since 2006. More than a research group, NUPES is a reference center for studies on spirituality and health in Brazil. Its influence in both an academic context and Brazilian society regarding the discussion of this topic is widely recognized. This group (which falls outside the search parameters applied in this study) will be described in more detail in the following section. 


\subsection{Research Center on Spirituality and Health (NUPES)—Federal University of Juiz de Fora (UFJF)}

Created in 2006, NUPES brings together researchers in the fields of medicine, psychology, neuroscience, nursing, physiotherapy, history, philosophy, and sociology and who supervise master's and doctoral students in the areas of medicine, public health, and psychology at the UFJF School of Medicine (Moreira-Almeida and Lucchetti 2016). As a research center, NUPES is not registered in the Directory of Research Groups; nevertheless, the center plays a prominent role in studies on S\&H in Brazilian academia. According to the NUPES website, nine researchers are investigating three lines of research: Epidemiology of Religiosity and Health, Religious and Spiritual Experiences, and History and Philosophy of Research on Spirituality (NUPES—Núcleo de Pesquisa Em Espiritualidade e Saúde n.d.).

Among the topics being researched are spiritual/religious coping; integration of S\&H into undergraduate courses in the area of health, the elderly, mediumship, and mental health; validation of scales; diagnoses that differentiate between mental disorder and religious experience, and the interrelationship between brain/mind and health outcomes. In the leadership of NUPES, Moreira-Almeida (lead researcher for the newly created Spirituality and Health Research Group, UFRJ-see Table 3) and Lucchetti (leader of the Research Group in Geriatrics and Gerontology - see Table 2) are both widely recognized in the field. NUPES has a channel on YouTube to disseminate the production of scientific knowledge to a broader, general public.

\subsection{Challenges and Potentialities of Research Groups in the Field of SEH: Some Considerations}

Given the growing interest in this topic, it is important to reflect on some of the challenges and potentialities for research groups interested in contributing to the advancement of knowledge in the field of S\&H in Brazil.

\subsubsection{A Starting Point that Should Be Considered by Beginners or "In-Process" Research Groups}

Sufficient studies exist that address the relationship between spirituality/religiosity and health and the necessity of integrating this theme into healthcare (Moreira-Almeida and Lucchetti 2016; Rocha et al. 2018b; Esperandio and Rosa 2020). As has been already pointed out by Moreira-Almeida and Lucchetti (2016), to contribute new information to the field of research, studies need to investigate (a) how spirituality/religiosity impacts health outcomes; (b) what should be considered an adequate integration of spiritual/religious issues into healthcare; (c) if, and to what extent, the spirituality/religiosity of health professionals might impact their own performance in healthcare (Rocha et al. 2020). Brazilian researchers can contribute a great deal to international studies given the population's highly religious behaviors.

\subsubsection{Searching for a Consistent Conceptualization of "Spirituality" and "Religiosity"}

The term "spirituality" is used more frequently in Brazilian academic circles than "religion" and "religiosity". Oman (2013) observed that the preference for the term "spirituality" has been more noticeable in a North American context since the 1970s. However, the author also noted that between 1970 and 2005, the use of the word "religion" in published works had a "modest" increase. On the other hand, the term "spirituality" had a "dramatic increase", approximately 40 times more, in the period between 2005 and 2009 (Oman 2013, p. 24), when compared to the period from 1970 to 2005. For Oman (2013, p. 28), the word "spirituality" started to be used in English as something that can explicitly be sought, not only within formal religious traditions but also outside of them; this trend started to become more evident at the end of the 20th century. A similar phenomenon can also be seen in Brazil. One of the direct implications of this finding is the need for a national consensus on the meaning and differentiation between the terms "spirituality" and "religiosity", including the term "spiritual care". It is assumed that a national consensus could contribute both to the advancement of theoretical-practical knowledge in the 
field of care ethics and to guide the implementation of spiritual care as a specialized (and integrated) service in multidisciplinary healthcare teams (particularly in palliative care services) (Esperandio and Leget 2020).

\subsubsection{Implications of the Conceptual Differentiation of Spirituality and Religiosity}

The need to develop a consistent theoretical framework for the differentiation of the terms "spirituality" and "religiosity" may assist in the construction of scales for assessing spirituality, as well as religiosity, in both the research and clinical contexts. Based on data from the last IBGE census (2010), it is possible to infer a significant increase in the number of people who identify as "spiritual", but not "religious". In this case, scales developed for the Brazilian context to assess the notion of spirituality and not just religiosity would be useful for future research as this would include a broader array of participants, as well as a more accurate picture of the Brazilian populations.

4.2.4. A Promising Research Topic: The Relationship between Religious Cognition, Religious Behavior, and Health Outcomes

Considering the religious diversity across the country, Brazil is a living laboratory for studies on the relationship between religious cognition (religious identity, mental representation, and supernatural attribution) of specific religious groups and global health. Studies on $\mathrm{S} \& \mathrm{H}$ could greatly contribute to the advancement of knowledge on this topic and other related sciences: psychiatry, the various currents of psychology (cognitive psychology of religion, cultural psychology of religion, and evolutionary psychology), bioethics, and theology. Such studies would be advantageous in Brazil in order to find psychological and behavioral differences between what the researchers call Western, Educated, Industrialized, Rich, and Democratic (WEIRD) societies and non-WEIRD populations. For instance, attendance at religious service has been strongly predictive of longevity in the West, especially in the USA, as noted by Oman (2018). Still, does some other specific spiritual/religious dimension demonstrate exceptional predictiveness in Brazil? The investigation of the Attachment Theory and the Attachment to God (August and Esperandio 2019; August and Esperandio 2020), for example, in mental health and the grieving processes would contribute to the quality of spiritual and psychological care to both bereaved family members in the context of palliative care and to people affected by COVID-19.

\subsubsection{Models of Spiritual Care}

Several studies have pointed to the importance of meeting the spiritual needs of sick people and their families. However, models of interdisciplinary spiritual care in the various health contexts (nursing, psychiatry, psychotherapeutic clinic, mental health, and palliative care, hospice) are scarce in Brazil, as well as internationally (Peteet and Balboni 2013). This demonstrates the necessity worldwide for the development of practical proposals with a theoretical base, such as the study developed by Mendonça et al. (2018) which offers a theoretical model of spiritual interventions based on Jean Watson's Theory of Human Care that can be applied in the context of oncological nursing.

\subsubsection{Specificities of Spiritual Assistance and Spiritual Care Education}

Studies highlighting the need to train various healthcare professionals on how to meet the spiritual needs of sick people and their families (Veras et al. 2019) are still scarce. Thus, the investigation of the specificities of spiritual care in distinct medical specialties which still maintain an interdisciplinary perspective can significantly contribute on at least two fronts: (1) formation of spiritual care competence in multidisciplinary healthcare teams, and (2) evidence-based subsidies to compose curriculum content in different areas of professional training. 


\subsubsection{The Need for a Critical Perspective on the Field}

National (Lucchese and Koenig 2013; Moreira-Almeida and Lucchetti 2016) and international (Koenig 2012) studies have shown that spirituality/religiosity has positive effects on health. However, the topic also demands a critical eye, i.e., spiritual/religious issues can trigger negative health outcomes, as noted by the gynecologist Cristião Rosas, who was mentioned in the beginning of this study. In this sense, it is essential to investigate the negative, as well as the positive, impact of spirituality/religiosity on health, e.g., spiritual/religious struggles and the extent to which they can cause harm to people's health.

\subsubsection{Training of Professional Spiritual Caregivers to Work in Multidisciplinary} Healthcare Teams

There is a lack of studies focusing on spiritual care that is offered by spiritual caregivers/chaplains who are part of multidisciplinary healthcare teams. However, this absence merely demonstrates the absence of these professionals in multidisciplinary teams. Spiritual assistance provided by spiritual caregivers is a topic neglected by the courses that should be the most concerned with it: theology and sciences of religion. This subject should matter in these disciplines, and studies need to be developed at the interface of bioethics, theology, and the sciences of religion in Brazil.

\subsubsection{Political Implications Concerning Spirituality as a Public Health Issue}

It is, finally, absolutely necessary that these research groups observe the political implications and social impact of their research. Given the religious diversity that characterizes the Brazilian cultural context, it is necessary to pay attention to spirituality/religiosity in public health promotion policies. Researchers in this field cannot be unaware of the political misuse of their findings. We cannot ignore the impact of religious beliefs in decision-making on health-related issues. As stated by Park (2014), global meaning (individuals' general orienting system) "has many effects on general aspects of health; further, its effects may be even more potent in the context of illness" (p. 21). We also have to be aware that those who are systematically excluded from more equitable and qualified care are the most vulnerable. In Brazil, not rarely, some religious and political leaders make use (or misuse) of people's faith, as became particularly evident in the pandemic context of COVID-19 (Bandeira and Carranza 2020). Our studies should take this population into account in the reflections on public health, $\mathrm{S} \& \mathrm{H}$, and vulnerable populations.

\section{Conclusions}

The analysis of the research groups on S\&H in Brazil showed the extent of possibilities in this field, given the undeniable interest of many Brazilian researchers in the subject. In this sense, the formation of research networks and greater dialogue between the groups seems essential to further enhance what is already presented as a "fruitful field". The list of nine items above is not intended to exhaust the data's discussion but to be the starting point for further discussions and possible other ways of promoting research in this field.

The investigation of this theme is still relatively young in Brazil. Opening the field up to the interdisciplinary dialogue that already characterizes the research while planning future research in this field with clear intentionality can result in major academic and social contributions. After all, we are talking about the investigation of the "spirit", the "breath of life", the "vital power" that is the condition for the continuity of life and its processes. The health of the vital potency is all that life needs in order to expand and assert itself in all its strength.

Supplementary Materials: The following are available online at https:/ /www.mdpi.com/2077-144 4/12/1/27/s1, Curriculum Vitae of Research Groups' Leaders and Researchers of Research Lines.

Funding: This research received no external funding.

Institutional Review Board Statement: Not applicable for this study.

Informed Consent Statement: Not applicable for this study. 
Data Availability Statement: No new data were created or analyzed in this study. Data sharing is not applicable to this article.

Acknowledgments: Gratitude to Linda Sauer Bredvik and Kevin Ladd for thoroughly reading the paper and for the valuable comments that contributed to improving the quality of this paper. Gratitude also to the anonymous reviewers for their careful reading and generous comments and suggestions.

Conflicts of Interest: The author declares no conflict of interest.

\section{References}

Abdala, Gina Andrade, Maria Dyrce Dias Meira, Gabriel Tagliari Rodrigo, Morenilza Bezerra da Conceição Fróes, Matheus Souza Ferreira, Sammila Andrade Abdala, and Harold George Koenig. 2020. Religion, Age, Education, Lifestyle, and Health: Structural Equation Modeling. Journal of Religion and Health 2020: 1-12. [CrossRef]

Aguiar, Paulo Rogerio, Silvio César Cazella, and Marcia Rosa Costa. 2017. A Religiosidade/Espiritualidade Dos Médicos de Família: Avaliação de Alunos Da Universidade Aberta Do SUS (UNA-SUS). Revista Brasileira de Educação Médica 41: 310-19. [CrossRef]

August, Hartmut, and Mary Esperandio. 2019. Attachment to god: Integrative review of empirical literature apego a deus: Revisão integrativa de literatura empírica. HORIZONTE—Revista de Estudos de Teologia e Ciências da Religião 17: 1039-72. [CrossRef]

August, Hartmut, and Mary Rute Gomes Esperandio. 2020. Teoria do apego e apego a deus no aconselhamento: Estudo de caso. Estudos Teológicos 60: 298-314. [CrossRef]

Bandeira, Olívia, and Brenda Carranza. 2020. Reactions to the Pandemic in Latin America and Brazil: Are Religions Essential Services? International Journal of Latin American Religions 4: 170-93. [CrossRef]

Carvalho, Guilherme D., Fernanda P. Costa, João Alberto M. Peruchi, Geris Mazzutti, Igor G. Benedetto, Josiane F. John, Lia A. Zorzi, Marcius C. Prestes, Marina V. Viana, Moreno C. Santos, and et al. 2019. The Quality of End-of-Life Care after Limitations of Medical Treatment as Defined by a Rapid Response Team: A Retrospective Cohort Study. Journal of Palliative Medicine 22: 71-74. [CrossRef]

Cavalcanti, Ana Paula Rodrigues, Carlos André Macêdo Cavalcanti, Carla Fernanda Ferreira-Rodrigues, Charlene Nayana Nunes Alves Gouveia, Deborah Dornellas Ramos, and Fagner José de Oliveira Serrano. 2012. Hipertensos de Baixa Renda e Recurso à Religiosidade como Estratégia de Controle. Diversidade Religiosa 2: 1-11. Available online: https://periodicos.ufpb.br/ojs2/index. $\mathrm{php} / \mathrm{dr} /$ article/view/11857 (accessed on 14 October 2018).

Cavalheiro, Carla Maria Frezza, and Denise Falcke. 2014. Espiritualidade Na Formação Acadêmica Em Psicologia No Rio Grande Do Sul. Estudos de Psicologia (Campinas) 31: 35-44. [CrossRef]

Conselho Nacional de Desenvolvimento Científico e Tecnológico (CNPq). 2020a. Manual do usuário: DGP—Diretório de Grupo de Pesquisa. O Diretório. Available online: http://lattes.cnpq.br/web/dgp/manual-do-usuario.www.rish.ch/pdf/Newsletter20062.pdf (accessed on 14 October 2018).

Costa, Milena Silva, Raphael Tavares Dantas, Cecília Gomes dos Santos Alves, Eugênia Rodrigues Ferreira, and Arthur Fernandes da Silva. 2019. Espiritualidade e Religiosidade: Saberes de Estudantes de Medicina. Revista Bioética 27: 350-58. [CrossRef]

Costa, Waldecíria, Conceição Nogueira, and Teresa Freire. 2010. The Lack of Teaching/Study of Religiosity/Spirituality in Psychology Degree Courses in Brazil: The Need for Reflection. Journal of Religion and Health 49: 322-32. [CrossRef]

Cunha, Vivian F., and Fabio S. Comin. 2019. ReligiositySpirituality (RS) in the Clinical Context: Professional Experiences of Psychotherapists. Temas Em Psicologia 27: 427-41. [CrossRef]

Curcio, Cristiane Schumann Silva, Giancarlo Lucchetti, and Alexander Moreira-Almeida. 2015. Validation of the Portuguese Version of the Brief Multidimensional Measure of Religiousness/Spirituality (BMMRS-P) in Clinical and Non-Clinical Samples. Journal of Religion and Health 54: 435-48. [CrossRef] [PubMed]

Esperandio, Mary. 2014. Teologia e a Pesquisa Sobre Espiritualidade e Saúde: Um Estudo Piloto Entre Profissionais da Saúde e Pastoralistas. HORIZONTE 12: 805-32. [CrossRef]

Esperandio, Mary, and Carlo Leget. 2020. Spirituality in palliative care in Brazil: An integrative literature review. REVER-Revista de Estudos da Religião 20: 29-45. [CrossRef]

Esperandio, Mary, and Kevin Ladd. 2015. I Heard the Voice. I Felt the Presence': Prayer, Health and Implications for Clinical Practice. Religions 6: 670-85. [CrossRef]

Esperandio, Mary Rute Gomes, and Geilson Antonio Silva Machado. 2018. Brazilian Physicians' Beliefs and Attitudes Toward Patients' Spirituality: Implications for Clinical Practice. Journal of Religion and Health 58: 1172-87. [CrossRef]

Esperandio, Mary Rute Gomes, and Luciana Fernandes Marques. 2015. The psychology of religion in Brazil. The International Journal for the Psychology of Religion 25: 255-71. [CrossRef]

Esperandio, Mary Rute Gomes, and Tiago Silva Rosa. 2020. Avaliação da espiritualidade/religiosidade de pacientes em cuidados paliativos. Protestantismo em Revista 46: 168-82. [CrossRef]

Esperandio, Mary, Fabiana Escudero, Marcio Fernandes, and Kenneth Pargament. 2018. Brazilian Validation of the Brief Scale for Spiritual/Religious Coping-SRCOPE-14. Religions 9: 31. [CrossRef]

Esperandio, Mary Rute Gomes, Hartmut August, Juan José Camou Viacava, Stefan Huber, and Marcio Luiz Fernandes. 2019. Brazilian validation of Centrality of Religiosity Scale (CRS-10BR and CRS-5BR). Religions 10: 508. [CrossRef] 
Espinha, Daniele Corcioli Mendes, Stéphanie Marques de Camargo, Sabrina Piccinelli Zanchettin Silva, Shirlene Pavelqueires, and Giancarlo Lucchetti. 2013. Opinião Dos Estudantes de Enfermagem Sobre Saúde, Espiritualidade e Religiosidade. Revista Gaúcha de Enfermagem 34: 98-106. [CrossRef] [PubMed]

Gomes, Antonio Marcos Tosoli, Sergio Corrêa Marques, Virginia Paiva Figueiredo Nogueira, Julio Cesar Cruz Collares-da-Rocha, Gerson Lourenço Pereira, Themistoklis Apostolidis, Luiz Carlos Moraes França, Karen Paula Damasceno dos Santos Souza, Magno Conceição das Merces, Pablo Luiz Santos Couto, and et al. 2020. A religiosidade para pessoas vivendo com HIV/Aids: Um estudo de representações sociais. Enfermagem Brasil 18: 750-58. [CrossRef]

Huber, Stefan, and Odilo W. Huber. 2012. The Centrality of Religiosity Scale (CRS). Religions 3: 710-24. [CrossRef]

Instituto Brasileiro de Geografia e Estatística (IBGE). 2010. Censo Demográfico 2010: Características gerais da população, religião e pessoas com deficiência. Rio de Janeiro: IBGE, pp. 1-215.

Koenig, Harold G. 2012. Religion, Spirituality, and Health: The Research and Clinical Implications. ISRN Psychiatry 2012: 1-33. [CrossRef] [PubMed]

Lucchese, Fernando A., and Harold G. Koenig. 2013. Religion, Spirituality and Cardiovascular Disease: Research, Clinical Implications, and Opportunities in Brazil. Brazilian Journal of Cardiovascular Surgery 28: 103-28. [CrossRef] [PubMed]

Lucchetti, Giancarlo, and Alessandra Granero. 2010. Integration of Spirituality Courses in Brazilian Medical Schools. Medical Education 44: 527-30. [CrossRef]

Lucchetti, Giancarlo, Alessandra Lamas Granero Lucchetti, Daniele Corcioli Mendes Espinha, Leandro Romani de Oliveira, José Roberto Leite, and Harold G. Koenig. 2012. Spirituality and Health in the Curricula of Medical Schools in Brazil. BMC Medical Education 12: 78. [CrossRef]

Lucchetti, Giancarlo, Harold G. Koenig, José Roberto Leite, and Alessandra L. G. Lucchetti. 2013. Medical students, spirituality and religiosity-results from the multicenter study SBRAME. BMC Medical Education 13: 162. [CrossRef]

Lucchetti, Alessandra, Ricardo Barcelos-Ferreira, Dan G. Blazer, and Alexander Moreira-Almeida. 2018. Spirituality in Geriatric Psychiatry. Current Opinion in Psychiatry 31: 373-77. [CrossRef]

Mainieri, Alessandra Ghinato, Julio Fernando Prieto Peres, Alexander Moreira-Almeida, Klaus Mathiak, Ute Habel, and Nils Kohn. 2017. Neural Correlates of Psychotic-like Experiences during Spiritual-Trance State. Psychiatry Research: Neuroimaging 266: 101-7. [CrossRef]

Matos, Ticiane Dionizio de Sousa, Silmara Meneguin, Maria de Lourdes da Silva Ferreira, and Helio Amante Miot. 2017. Quality of Life and Religious-Spiritual Coping in Palliative Cancer Care Patients. Revista Latino-Americana de Enfermagem 25. [CrossRef] [PubMed]

Mena-Chalco, Jesús Pascual, and Roberto Marcondes Cesar Junior. 2009. ScriptLattes: An Open-Source Knowledge Extraction System from the Lattes Platform. Journal of the Brazilian Computer Society 15: 31-39. [CrossRef]

Mendonça, Angelo Braga, Eliane Ramos Pereira, Bruna Maiara Ferreira Barreto, and Rose Mary Costa Rosa Andrade Silva. 2018. Counseling and spiritual assistance to chemotherapy patients: A reflection in the light of Jean Watson's Theory. Escola Anna Nery 22. [CrossRef]

Menegatti-Chequini, Maria C., Everton de O. Maraldi, Mario F. P. Peres, Frederico C. Leão, and Homero Vallada. 2019. How Psychiatrists Think about Religious and Spiritual Beliefs in Clinical Practice: Findings from a University Hospital in São Paulo, Brazil. Brazilian Journal of Psychiatry 41: 58-65. [CrossRef]

Ministério da Educação. 2020a. Apresentação-Portal CNPq. Available online: http://www.cnpq.br/web/guest/apresentacao_ institucional/ (accessed on 22 November 2018).

Brazil, Ministério da Educação. 2020b. Coordination for the Improvement of Higher Education Personnel. Available online: https: / / www.iie.org:443/Programs / CAPES (accessed on 22 November 2018).

Moreira-Almeida, Alexander, and Giancarlo Lucchetti. 2016. Panorama das pesquisas em ciência, saúde e espiritualidade. Ciência e Cultura 68: 54-57. [CrossRef]

Moreira-Almeida, Alexander, Francisco Lotufo Neto, and Harold G Koenig. 2006. Religiousness and Mental Health: A Review. Revista Brasileira de Psiquiatria 28: 242-50. [CrossRef]

Moreira-Almeida, Alexander, Ilana Pinsky, Marcos Zaleski, and Ronaldo Laranjeira. 2010. Envolvimento Religioso e Fatores Sociodemográficos: Resultados de Um Levantamento Nacional No Brasil. Archives of Clinical Psychiatry (São Paulo) 37: 12-15. [CrossRef]

NUPES—Núcleo de Pesquisa Em Espiritualidade e Saúde. n.d. Available online: https://www.ufjf.br/nupes/pesquisadores/ (accessed on 15 October 2020).

Nwora, Emmanuel Ifeka, and Marta Helena de Freitas. 2020. Relações entre religiosidade e saúde mental na concepção de capelães. REVER-Revista de Estudos da Religião 20: 199-217. [CrossRef]

Oliveira, Raquel Aparecida de. 2017. Saúde e Espiritualidade Na Formação Profissional Em Saúde, Um Diálogo Necessário. Revista Da Faculdade de Ciências Médicas de Sorocaba 19: 54-55. [CrossRef]

Oliveira, Joana. 2020. Cristião Rosas, médico: O aborto legal é um direito. A influência religiosa faz mal à saúde e põe vidas em risco. EL PAÍS. August 30. Available online: https://brasil.elpais.com/brasil/2020-08-30/cristiao-rosas-medico-o-aborto-legal-e-umdireito-a-influencia-religiosa-faz-mal-a-saude-e-poe-a-vida-em-risco.html (accessed on 15 October 2020). 
Oliveira da Silva, Cassiano Augusto, Ana Paula Rodrigues Cavalcanti, Kaline da Silva Lima, Carlos André Macêdo Cavalcanti, Tânia Cristina de Oliveira Valente, and Arndt Büssing. 2020a. Item Response Theory Applied to the Spiritual Needs Questionnaire (SpNQ) in Portuguese. Religions 11: 139. [CrossRef]

Oliveira da Silva, Cassiano Augusto, Ana Paula Rodrigues Cavalcanti, Kaline da Silva Lima, Carlos André Macêdo Cavalcanti, Tânia Cristina de Oliveira Valente, and Arndt Büssing. 2020b. Spiritual Needs Questionnaire (SpNQ): Validity Evidence among HIV+ Patients in Northeast Brazil. Religions 11: 234. [CrossRef]

Oliveira, Rafael Moura, Rose Manuela Marta Santos, and Sérgio Donha Yarid. 2018. Espiritualidade/religiosidade e o humanizaSUS em Unidades de Saúde da Família. Revista Brasileira em Promoção da Saúde 31. [CrossRef]

Oman, Doug. 2013. Defining religion and spirituality. In Handbook of the Psychology of Religion and Spirituality, 2nd ed. Edited by Raymond F. Paloutzian and Crystal L. Park. New York and London: The Guilford Press, pp. $24-47$.

Oman, Doug. 2018. What's next?: Public health and spirituality. In Why Religion and Spirituality Matter for Public Health. Edited by Doug Oman. Cham: Springer International Publishing, pp. 463-68. [CrossRef]

Paiva, Carlos Eduardo, Bianca Sakamoto Ribeiro Paiva, Sriram Yennurajalingam, and David Hui. 2014. The Impact of Religiosity and Individual Prayer Activities on Advanced Cancer Patients' Health: Is There Any Difference in Function of Whether or Not Receiving Palliative Anti-Neoplastic Therapy? Journal of Religion and Health 53: 1717-27. [CrossRef] [PubMed]

Paiva, Bianca Sakamoto Ribeiro, André Lopes Carvalho, Giancarlo Lucchetti, Eliane Marçon Barroso, and Carlos Eduardo Paiva. 2015. 'Oh, Yeah, I'm Getting Closer to God': Spirituality and Religiousness of Family Caregivers of Cancer Patients Undergoing Palliative Care. Supportive Care in Cancer 23: 2383-89. [CrossRef] [PubMed]

Park, Crystal L. 2014. Meaning, Spirituality, and Health: A Brief Introduction. Revista Pistis Praxis 6: 17. [CrossRef]

Pereira, Karine Costa Lima, and Adriano Furtado Holanda. 2019. Religião e Espiritualidade No Curso de Psicologia: Revisão Sistemática de Estudos Empíricos. Interação Em Psicologia 23. [CrossRef]

Peteet, John R., and Michael J. Balboni. 2013. Spirituality and religion in oncology: Spirituality and religion in oncology. CA: A Cancer Journal for Clinicians 63: 280-89. [CrossRef]

Reis, Camila Calhau Andrade, Edite Lago da Silva Sena, and Tânia Maria de Oliva Menezes. 2016. Experiences of Family Caregivers of Hospitalized Elderlies and the Experience of Intercorporeality. Escola Anna Nery—Revista de Enfermagem 20: 1-6. [CrossRef]

Rocha, Renata Carla Nencetti Pereira, Eliane Ramos Pereira, and Rose Mary Costa Rosa Andrade Silva. 2018a. The spiritual dimension and the meaning of life in nursing care: Phenomenological approach. REME: Revista Mineira de Enfermagem 22: e-1151. [CrossRef]

Rocha, Renata Carla Nencetti Pereira, Eliane Ramos Pereira, Rose Mary Costa Rosa Andrade Silva, Angelica Yolanda Bueno Bejarano Vale de Medeiros, and Aline Miranda da Fonseca Marins. 2020. O sentido da vida dos enfermeiros no trabalho em cuidados paliativos: Revisão integrativa de literatura. Revista Eletrônica de Enfermagem 22: 56169. [CrossRef]

Rocha, Renata Carla Nencetti Pereira, Eliane Ramos Pereira, Rose Mary Costa Rosa Andrade Silva, Angelica Yolanda Bueno Bejarano Vale de Medeiros, Sueli Maria Refrande, and Neusa Aparecida Refrande. 2018b. Spiritual needs experienced by the patient's family caregiver under oncology palliative care. Revista Brasileira de Enfermagem 7: 2635-42. [CrossRef] [PubMed]

Santos, Neyde Cintra dos, and Gina Andrade Abdala. 2014. Religiosidade e qualidade de vida relacionada à saúde dos idosos em um município na Bahia, Brasil. Revista Brasileira de Geriatria e Gerontologia 17: 795-805. [CrossRef]

Sens, Guilherme Ramos, Gina Andrade Abdala, Maria Dyrce Dias Meira, Silvana Bueno, and Harold G. Koenig. 2019. Religiosity and Physician Lifestyle from a Family Health Strategy. Journal of Religion and Health 58: 628-38. [CrossRef] [PubMed]

Silva, Alexander Cangussu, Oscarina da Silva Ezequiel, Rodolfo Furlan Damiano, Alessandra Lamas Granero Lucchetti, Lisabeth Fisher DiLalla, J. Kevin Dorsey, and Giancarlo Lucchetti. 2018. Translation, Transcultural Adaptation, and Validation of the Empathy, Spirituality, and Wellness in Medicine Scale to the Brazilian Portuguese Language. Teaching and Learning in Medicine 30: 404-14. [CrossRef] [PubMed]

Silva, Annaterra Araújo, Antonio Marcos Tosoli Gomes, Ana Cristina Santos Duarte, and Sergio Donha Yarid. 2020. Influência do coping religioso-espiritual no luto materno. Enfermagem Brasil 19: 310-16. [CrossRef]

Silva, Gabriela Cruz Noronha, Dáfili Cristina dos Reis, Talita Prado Simão Miranda, Ruan Nilton Rodrigues Melo, Mariana Aparecida Pereira Coutinho, Gabriela dos Santos Paschoal, and Érika de Cássia Lopes Chaves. 2019. Religious/Spiritual Coping and Spiritual Distress in People with Cancer. Revista Brasileira de Enfermagem 72: 1534-40. [CrossRef] [PubMed]

Veras, Sylvia Maria Cardoso Bastos, Tânia Maria de Oliva Menezes, Raúl Fernando Guerrero-Castañeda, Mateus Vieira Soares, Florencio Reverendo Anton Neto, Gildásio Souza Pereira, and Sylvia Maria Cardoso Bastos Veras. 2019. Nurse care for the hospitalized elderly's spiritual dimension. Revista Brasileira de Enfermagem 72: 236-42. [CrossRef]

Vitorino, Luciano M., Raíssa Chiaradia, Gail Low, Jonas Preposi Cruz, Kenneth I. Pargament, Alessandra L. G. Lucchetti, and Giancarlo Lucchetti. 2018. Association of Spiritual/Religious Coping with Depressive Symptoms in High- and Low-risk Pregnant Women. Journal of Clinical Nursing 27. [CrossRef] 